\title{
KONSEP GREEN MARKETING DAN DAMPAKNYA TERHADAP PERILAKU KONSUMEN INDONESIA
}

\author{
Lu'lu'ul Jannah, S.E., M.Si \\ Sekolah Tinggi Ilmu Ekonomi Media Nusantara Citra \\ luluul.jannah@stiemnc.ac.id \\ Erni Hernawati, S.E., M.Ak \\ Sekolah Tinggi Ilmu Ekonomi Media Nusantara Citra \\ erni.hernawati@stiemnc.ac.id
}

\begin{abstract}
The purpose of this study is to determine the concept of green marketing on Indonesian consumer behavior. The data analysis method was carried out by using regression analysis either partially or simultaneously. The results showed that the attitude and environment partially influenced the involvement of green products, while the attitude environment and the involvement of green products simultaneously influenced the involvement of Indonesian society in purchasing green products in selecting products. And the results of the simultaneous regression analysis from the ANOVA test with a significance level of 0.000. Because the significant probability is much smaller than 0.05, this indicates that simultaneously it states that there is an effect of attitude environment and the involvement of green products simultaneously influencing the involvement of green product purchases.
\end{abstract}

Keywords: Green Marketing, Environmental Attitudes, Green Product Purchasing Involvement

\begin{abstract}
ABSTRAK
Tujuan penelitian ini adalah untuk mengetahui konsep pemasaran hijau pada perilaku konsumen indonesia. Metode analisis data dilakukan dengan mengunakan analisis regresi baik secara parsial maupun secara simultan. Hasil penelitian menunjukkan bahwa attitude environmet memengaruhi secara parsial pada keterlibatan green product sedangkan attitude environment dan keterlibatan green product secara simultan mempengaruhi keterlibatan pembelian green product masyarakat Indonesia dalam memilih produk. Dan hasil analisis regresi secara simultan dari uji ANOVA dengan tingkat signifikasi 0.000 . Karena probabilitas signifikan jauh lebih kecil dari 0.05 maka hal ini menunjukan bahwa secara simultan menyatakan bahwa ada pengaruh attitude environment dan keterlibatan green product secara simultan mempengaruhi keterlibatan pembelian green product.
\end{abstract}

Kata kunci: Pemasaran Hijau, Sikap Lingkungan, Keterlibatan Pembelian Produk Hijau 


\section{PENDAHULUAN}

Selama dekade terakhir, lingkungan berkelanjutan telah tumbuh di masyarakat umum sekitar dunia, dan masih akan terus tumbuh dengan munculnya berbagai masalah lingkungan global. Pada tahun 2017, survei menemukan bahwa hingga 80 persen konsumen global merasa bahwa perusahaan harus melakukannya berkontribusi pada peningkatan lingkungan, dengan signifikansi di kawasan berkembang seperti Asia Pasifik, dan Amerika Latin, diikuti oleh kawasan yang lebih maju seperti Amerika Utara, dan Eropa (Nielsen: Survei Kepercayaan Konsumen Global). Berkenaan dengan masalah ini, konsumen sudah mulai menyesuaikan kebiasaan belanja mereka, dan menjadi lebih selektif memilih produk sesuai dengan fitur keberlanjutannya. Konsumen yang mencari produk ramah lingkungan telah menjadi faktor penting di balik cara perusahaan beroperasi sehingga hal ini mendorong perusahaan untuk memasarkan produknya dengan lebih banyak penekanan pada tanggung jawab lingkungan yang dikenal sebagai green marketing. Pemasaran seperti ini merupakan upaya untuk menerapkan lebih banyak fitur keberlanjutan seperti: bahan ramah lingkungan, kemasan dapat digunakan kembali pengemasan, dan lain sebagainya. Meskipun demikian, komunikasi melalui alat promosi merek juga akan memenuhi tujuannya untuk menyampaikan pesan yang lebih berpengaruh terkait dengan keberlanjutan kesadaran. Selain itu, diperkirakan industri "green product" telah berakhir \$ 200 miliar pada tahun 2006 dan dengan perkiraan baru-baru ini oleh Nielsen memproyeksikan produk keberlanjutan akan dijual lebih dari \$ 150 miliar pada tahun 2021 di Amerika Serikat saja (Nielsen, 2018). Sebagai salah satu kawasan utama konsumen hijau di kawasan AsiaPasifik, Indonesia juga memiliki populasi yang cukup besar, dan dianggap sebagai pesaing kelas konsumen dunia pada tahun 2030 setelah penambahan 90 juta konsumen bersaing dengan China dan India pasar yang berkembang (Budiman, 2013), (Septifani, Achmadi, \& Santoso, 2014). Indonesia juga telah diproyeksikan oleh Mckinsey Global Institute menjadi ekonomi terbesar ketujuh di dunia pada tahun 2030, melampaui Jerman dan Inggris Raya. Selain itu, sampah plastik telah menjadi perhatian yang signifikan di antara masyarakat Indonesia saat ini 
bersama dengan masalah lingkungan lainnya yang dipicu berbagai aksi unjuk rasa dan demonstrasi yang dipimpin oleh aktivis lingkungan. Namun, regulasi dan infrastruktur Indonesia hanya menunjukkan sedikit kemajuan isu yang berkaitan dengan lingkungan. Meskipun perhatian negara tidak signifikan, ada tren yang berkembang menggunakan produk daur ulang dan lebih berkelanjutan di kalangan konsumen Indonesia, khususnya generasi muda (Arafah, 2018). Botol dan tas yang dapat digunakan kembali telah muncul beberapa tahun terakhir, meskipun budaya daur ulang mereka belum secanggih Jerman di mana tempat daur ulang botol tersedia di setiap supermarket (Rastogi \& Pant, 2018). Selain itu, green marketing dapat digunakan untuk mendapatkan keunggulan kompetitif setelah melakukan analisis berbagai merek Indonesia (2011), dan gagasan serupa dihadirkan dalam sebuah riset konsumen yang dilakukan di Mauritius pada tahun berikutnya yang memiliki minat baru untuk penelitian lebih lanjut tentang pasar negara berkembang seperti Indonesia yang berkaitan dengan

TELAAH LITERATUR

Green Marketing green marketing. Sekarang karena produk ramah lingkungan masih dalam fase pertumbuhannya ke pasar Indonesia, oleh karena itu saatnya perlu mempelajari bagaimana konsumen berperilaku terhadap produk ramah lingkungan dan memeriksa bagaimana pemasaran green product yang tersedia saat ini memengaruhi proses pembelian konsumen. Adapun pertanyaan yang mau dijawab oleh peneliti antara lain sebagai berikut:

1. Apakah attitude environmet mempengaruhi keterlibatan green product masyarakat Indonesia dalam memilih produk?

2. Apakah attitude environment dan keterlibatan green product mempengaruhi keterlibatan pembelian green product masyarakat Indonesia dalam memilih produk

3. Sejauh mana pemasaran ramah lingkungan mempengaruhi masyarakat Indonesia untuk mempertahankan lingkungan mereka dalam mengkonsumsi produk?

Seperti yang didefinisikan oleh (Schiffman \& Wisenbilt, 2019) green 
marketing adalah memproduksi dan mempromosikan produk yang dapat digunakan kembali, dan ramah lingkungan. Selama 20 tahun terakhir, perusahaan telah mengadopsi praktik yang lebih berkelanjutan dan ramah lingkungan dalam pengoperasian, serta memproduksi barang sebagai tanggapan atas kesadaran global terhadap keberlanjutan dan iklim perubahan. Misalnya, bahan pengganti plastik telah beredar di pasaran dan ditampilkan dengan pesan keberlanjutan. Pesanpesan ini sekarang umum digunakan oleh pemasar untuk menginformasikan kepada konsumen bahwa merek tersebut sekarang menggunakan bahan bakar terbarukan, daur ulang, dan non polusi bahan. Lebih jauh lagi, (Pickett \& Ozaki, 2008) mengatakan bahkan merasa sadar lingkungan konsumen kesulitan mengidentifikasi produk "hijau", dan tidak menemukan pemasaran yang tepat menarik. Dengan kata lain green marketing sangat menggembirakan konsumen untuk mempertimbangkan norma-norma lingkungan dan sosial selama waktu pembelian, penggunaan, dan bahkan pembuangan produk.

\section{Green Consumers}

(Esmaeilpour \& Bahmiary, 2017) mendefinisikan produk ramah lingkungan sebagai produk yang dirancang di acara tertentu untuk mengeluarkan dampak lingkungan paling sedikit baik selama produksi dan konsumsi. Produk ramah lingkungan membantu melindungi dan melestarikan lingkungan alam dengan melakukan pelayanan energi, mengurangi penggunaan zat beracun, dan mengelola limbah dan polusi. Lebih lanjut, salah satu definisi menyatakan bahwa bahan yang digunakan untuk menghasilkan warna hijau produk dapat didaur ulang lebih lanjut, sehingga menciptakan efisiensi energi dan polusi lebih sedikit dibandingkan praktik produksi lainnya. Berkaitan dengan produk ramah lingkungan di Indonesia, tren yang terus berlanjut produk pengganti yang ramah lingkungan selama beberapa tahun terakhir, sebagai respon terhadap plastik masalah sampah di negara ini. Mengingat masalah ini, banyak produsen terutama bisnis kecil sudah mulai menggunakan dan menjual bahan non-plastik untuk produk-produk yang biasa terbuat dari plastik. Selain itu juga fenomena ini, semakin banyak toko kecil khusus dengan ramah lingkungan 
yang baru buka beberapa tahun terakhir, menjual berbagai produk rumah tangga dan kebutuhan lainnya. Selain itu, produk ramah lingkungan juga dapat ditemukan di pengecer rumah yang lebih besar untuk produk seperti, cat, deterjen, dan lainnya pembersih yang dapat terurai secara hayati.

\section{Green consumers}

(Lu, Bock, \& Joseph, 2013) mengatakan bahwa dalam peningkatan kesadaran keberlanjutan global, kepedulian terhadap lingkungan menjadi perhatian untuk mengarahkan beberapa konsumen untuk mengubah perilaku pembelian mereka. Jenis konsumen ini telah muncul untuk mengikuti kesadaran global yang dikenal sebagai "konsumen hijau". Green consumers adalah orang-orang yang sangat peduli dan sadar tentang lingkungan, oleh karena itu memodifikasi pembelian perilaku konsumen adalah salah satu cara mereka dapat berkontribusi dalam konteks konsumsi produk. Mereka juga memperhatikan implikasi proses produksi terhadap lingkungan, Oleh karena itu mereka menginginkan produk yang tidak hanya tidak berbahaya bagi lingkungan, tetapi juga melindunginya dirinya sendiri. Umumnya, konsumen ini akan menghindari membeli produk yang mungkin berbahaya bagi kesehatan mereka mulai dari mengkonsumsi tingkat energi yang signifikan, menciptakan pemborosan, menimbulkan ancaman besar bagi lingkungan alam, serta membahayakan makhluk hidup lain seperti hewan, dan tumbuhan. Seiring pertumbuhan green consumers dalam beberapa tahun terakhir, pemasar telah menemukan jenis konsumen ini menjadi prospek yang menarik, dan tidak mengherankan jika pemasar juga mencoba melakukannya jelajahi mereka. Menurut (Lu, Bock, \& Joseph, 2013) ada beberapa jenis terkait green consumers antara lain sebagai berikut:

1. True Greens: Konsumen ini telah menerapkan gaya hidup ramah lingkungan, dan juga mencoba meyakinkan orang di sekitar mereka untuk menggunakan produk ramah lingkungan daripada yang umum. Jenis konsumen ini akan berganti merek karena alasan ekologis, dan bersedia berbuat ekstra atau berkorban demi melindungi lingkungan. 
2. Donor Greens: Jenis konsumen ini merasa bersalah karena kurangnya keberlanjutan konsumsi, dan terkadang mempertimbangkan dampak lingkungan saat membeli. Meskipun mereka tidak mau mengubah konsumsinya, mereka bersedia menjadikannya pribadi pengorbanan finansial untuk menopang planet ini.

3. Learning Green: Konsumen ini masih dalam proses belajar tentang masalah lingkungan dan keberlanjutan. Mereka tidak aktif dalam inisiatif ekologi apa pun, tetapi terkadang mempertimbangkan dampak lingkungan pada pembelian mereka. Namun, mereka memang demikian skeptis terhadap klaim yang dibuat oleh ahli lingkungan.

4. Non Green: Konsumen ini tidak peduli atau peduli tentang masalah lingkungan, juga tidak dampak dari pembelian mereka. Meski beberapa dari mereka mengakui keberadaan masalah lingkungan, mereka masih membeli produk non-hijau, dan tidak merasa bersalah karenanya. Konsumen juga mentolerir praktik perusahaan yang tidak berkelanjutan terhadap lingkungan.

\section{Environmental attitude}

Menurut (Schiffman \& Wisenbilt, 2019) secara umum, sikap konsumen diartikan sebagai kecenderungan yang dipelajari untuk mencerminkan suatu yang menguntungkan atau evaluasi yang tidak menguntungkan terhadap suatu produk. mendefinisikan sikap sebagai indera emosional dalam diri individu yang berperan penting dalam meramalkan perilaku Sikap dipelajari dari pengalaman sebelumnya, paparan media massa, dan lingkungan sosial seperti keluarga dan teman. Mirip dengan motivasi, sosial norma juga dapat mempengaruhi sikap konsumen, itulah sebabnya konsumerisme hijau dapat berkontribusi tren. Dalam tiga komponen sikap - kognitif, afektif, dan konatif - pemasar telah mengeksplorasi bagaimana sikap dapat diubah atau dialihkan menggunakan pesan persuasif dan isyarat. Ide utama di balik mengubah sikap konsumen adalah disajikan dalam Elaboration Likelihood Model (ELM) oleh Petty dan Cacioppo, 
dimana prosesnya akan melalui jalur sentral. Selanjutnya, berkaitan dengan file Perubahan sikap bertahan dalam diri konsumen hijau, membutuhkan evaluasi kognitif selama ini rute pusat. Proses perubahan sikap inilah yang menjadi argumentasi salah satu penelitian pertanyaan dalam penelitian ini, yaitu untuk mengetahui hubungan antara perubahan sikap, produk, dan keterlibatan pembelian untuk produk ramah lingkungan. Sikap lingkungan

\section{METODOLOGI PENELITIAN}

Pendekatan penelitian ini bertujuan untuk memahami mekanisme perilaku konsumen berkaitan dengan variabelvariabel yang berkorelasi dikumpulkan dengan data empiris. Desain penelitian ini dengan menggunakan pendekatan cross-sectional karena hanya akan mengkaji data yang dikumpulkan di bulan Januari dan Februari 2021, dan tidak akan menampilkan data tindak lanjut di periode selanjutnya. Responden yang memenuhi syarat penelitian ini hanya akan didasarkan pada konsumen Indonesia yang pernah atau secara teratur membeli produk ramah lingkungan. Metode pengambilan sampel yang dipilih adalah non-probabilitas yang mana kemudahan diartikan sebagai sikap di mana masalah lingkungan dan konsekuensi dipertimbangkan. Pertimbangan ini bisa dinilai sesuai dengan kekhawatiran tentang lingkungan seperti: dampak produk terhadap lingkungan, tingkat konsumsi energi, dan lain-lain. Karena itu, masalah lingkungan dikaitkan dengan sikap dan perilaku konsumen

pengambilan sampel ini dengan waktu penelitian yang terbatas dengan menggunakan kuesioner online. Di dalam kuesioner, akan menyaring pertanyaan akan ditanyakan di awal untuk memvalidasi kualifikasi responden yang meliputi, pengalaman membeli produk ramah lingkungan, serta frekuensi pembelian. Jumlah sampel yang di dapat sebanyak 107 responden. Kuesioner yang dibagikan terdiri dari lima bagian. Bagian pertama diisi dengan pertanyaan terkait demografis, serta pertanyaan penyaring. Bagian kedua diisi dengan pertanyaan tentang motivasi pembelian, dan jenis produk yang dibeli. Dan terakhir di bagian 3 sampai 5 terdiri dari pernyataan yang terkait dengan 
variabel: sikap lingkungan, keterlibatan pembelian produk ramah lingkungan, dan keterlibatan produk ramah lingkungan. Masing-masing pernyataan ini disajikan dengan skala Likert 5 poin untuk diisi berkenaan dengan tingkat kesepakatan dari responden Skala akan berkisar dari 1 (sangat tidak setuju), 2 (tidak setuju), 3 (kurang setuju), 4 (setuju), 5 (sangat setuju). Berkenaan dengan analisis data, serangkaian pengujian dijalankan menggunakan perangkat lunak SPSS, yang meliputi: reliabilitas, korelasi, dan analisis regresi. Sehubungan dengan tujuan pengujian, uji reliabilitas adalah

\section{HASIL DAN PEMBAHASAN}

Berikut ini dari hasil pembahasan dari profil demografi responden, motivasi pembelian, dan frekuensi pembelian yang selanjuntnya nantinya akan dilakukan untuk mengukur sejauh mana timbangan menghasilkan hasil yang konsisten jika diulang pengukuran dimasukkan ke dalam variabel. Korelasi Pearson digunakan dan tingkat signifikansi akan menentukan tingkat korelasi antara item atau variabel. Terakhir, adalah analisis regresi. Analisis regresi digunakan untuk mengukur hubungan antara masingmasing variabel. Pengujian hipotesis disimpulkan dengan memperhitungkan nilai-nilai berikut: $r$ square, beta, dan nilai signifikansi.

membahas reliabilitas, korelasi, dan regresi.

\section{Kelompok Umur}

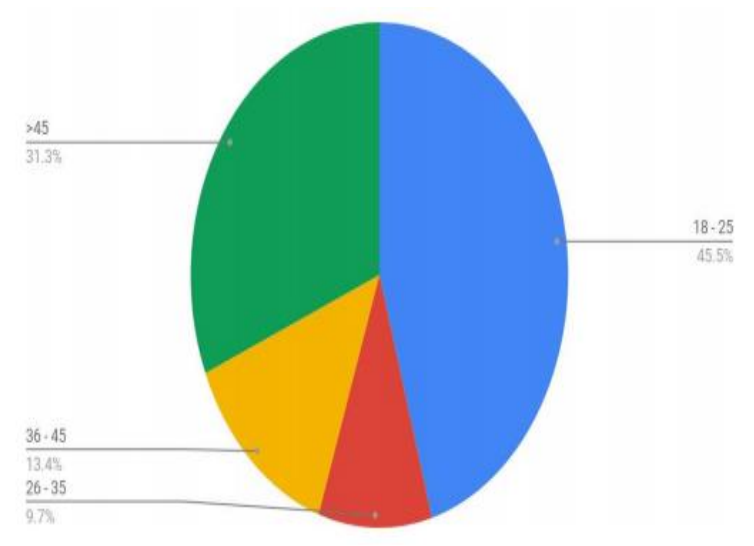




\section{Gambar 1 Profil Responden Berdasarkan Kelompok Umur}

2.Jenis Kelamin

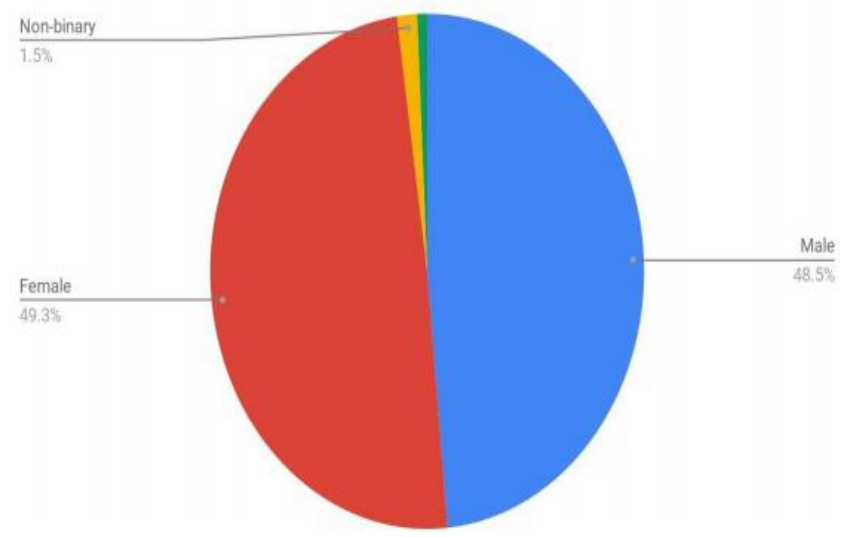

Gambar 2 Profil Responden Berdasarkan Jenis Kelamin

Seperti yang ditunjukkan pada Gambar

1 dan 2, responden teratas sebagian besar adalah orang-orang yang usia kisaran 18 hingga 25 tahun, diikuti oleh mereka yang berusia di atas 45 . Meskipun profil demografis ini tidak diuji dengan korelasi dengan variabel lain, akan tetapi informasi ini menjelaskan pelanggan yang menggunakan produk ramah lingkungan tersebut mulai dari kelompok usia yang berbeda, serta jenis kelamin.

3. Pengalaman dalam membeli green product

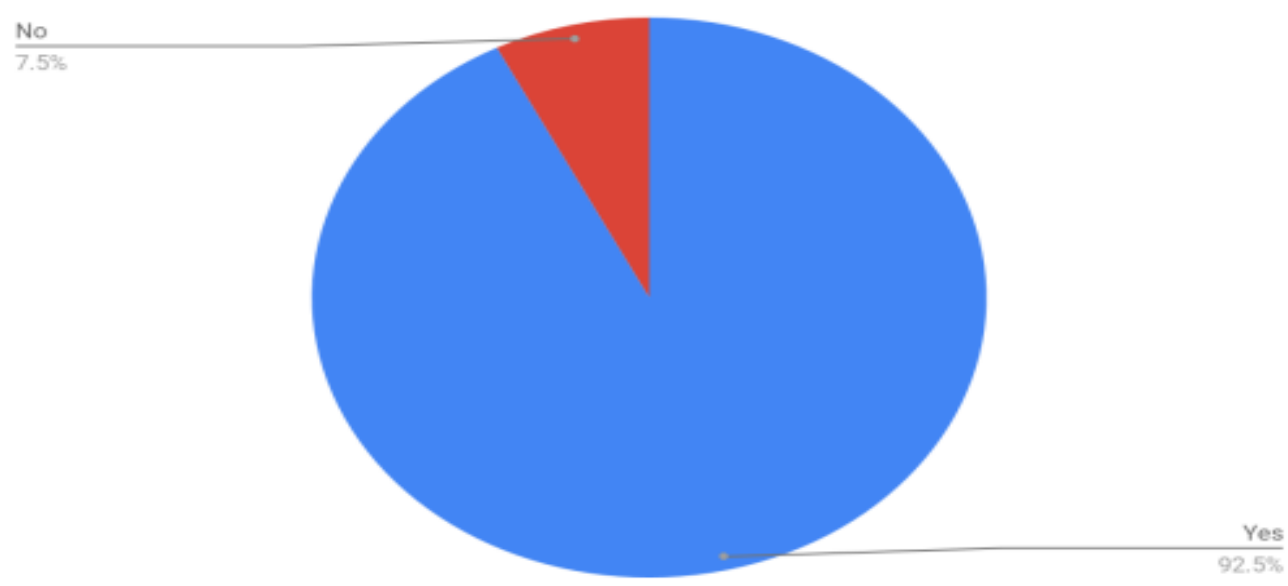

Gambar 3 Profil Responden Berdasarkan Pengalaman Membeli Green Product

Seperti yang ditunjukkan pada Gambar

4, dari seluruh responden, lebih dari 90 persen di antaranya memiliki pengalaman dalam membeli green 
product. Hal ini menunjukkan bahwa konsumen Indonesia lebih banyak mengetahui tentang produk ramah lingkungan, dan bahwa produk ramah lingkungan cukup umum di kalangan konsumen, terlepas dari tren gaya hidup yang berkelanjutan masih berkembang di Indonesia. Hal ini juga terlihat pada

\section{Frekuensi pembelian green product}

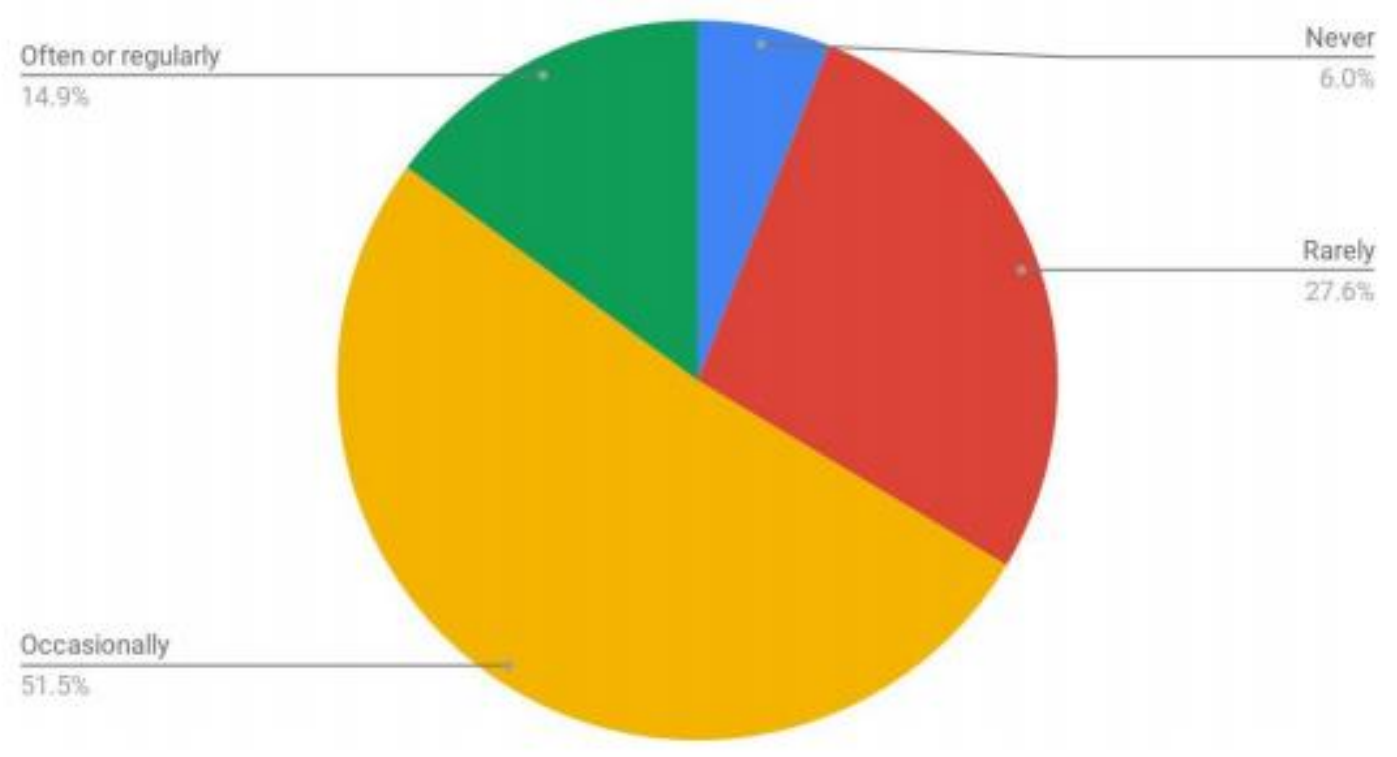

Gambar 4 Profil Responden Berdasarkan Membeli Green Product

Berkenaan dengan motivasi pembelian, Gambar 6 menunjukkan bahwa motivasi utama konsumen adalah memang didasarkan pada masalah lingkungan. Namun, perlu juga diketahui bahwa konsumen termotivasi membeli barang juga mencakup produk itu sendiri. Hal ini menunjukkan bahwa konsumen telah mengetahui komunikasi
Gambar 5 yang paling banyak mereka membeli produk ramah lingkungan sesekali atau jarang. Ini menunjukkan bahwa pembeli pada umumnya masih sedikit, dan gaya hidup dengan konsep green masih belum tumbuh lebih banyak. 
Tabel di bawah ini menunjukkan hasil analisis reliabilitas dari masing-masing variabel menggunakan Cronbach's Alpha yang digunakan untuk memastikan konsistensi setiap pernyataan yang akan diajukan untuk didistribusikan dalam survei mengacu pada masing-masing variabel.

Tabel 1 Hasil Reliabilitas Antar Variabel

\begin{tabular}{|l|c|c|c|c|}
\hline \multicolumn{1}{|c|}{ Variable } & Cronbach alpha & $\begin{array}{c}\text { Acceptable } \\
\text { level }\end{array}$ & $\begin{array}{c}\text { No. of } \\
\text { items }\end{array}$ & Conclusion \\
\hline $\begin{array}{l}\text { Environmental } \\
\text { concerns }\end{array}$ & .864 & $>0.7$ & 4 & Acceptable \\
\hline $\begin{array}{l}\text { Green products } \\
\text { purchase involvement }\end{array}$ & .810 & $>0.7$ & 3 & Acceptable \\
\hline $\begin{array}{l}\text { Green product } \\
\text { involvement }\end{array}$ & .844 & $>0.7$ & 5 & Acceptable \\
\hline
\end{tabular}

Agar dapat dianggap reliabilitas untuk setiap variabel maka Cronbach's Alpha perlu lebih besar dari 0,7 (Malhotra, 2017). maka dari hasil pengolahan diperoleh nilai Cronbach Alpha lebih besar dari 0,7 , sehingga dengan demikian dapat diakatakan semua variabel dikatakan reliabilitas.

Korelasi

Analisis korelasi bertujuan untuk mengukur kekuatan asosiasi antara dua variabel yang dapat diukur. Nilai korelasi berkisar antara -1 sampai 1 dengan nilai positif yang berarti hubungan linier positif, dan nilai negatif berarti hubungan linier negatif antara kedua variabel. Selanjutnya nilai signifikansi tersebut akan diinterpretasikan sebagai signifikansi statistik. Oleh karena itu, jika nilai signifikansi lebih besar dari tingkat signifikansi $(0,05)$, maka korelasi tersebut secara statistik tidak signifikan. Pengujian dilakukan dengan menggunakan Korelasi Pearson dan signifikansi 1-sisi. Tiga uji korelasi dilakukan dengan variabel yang terdaftar sebagai berikut:

1. Frekuensi pembelian dan keterlibatan pembelian green product.

2. Frekuensi pembelian dan attitude environment. 
3. Frekuensi pembelian dan keterlibatan

Uji korelasi 1: Frekuensi pembelian dan keterlibatan produk ramah lingkungan produk ramah lingkungan.

Tabel berikut menunjukkan hasil korelasi antara Frekuensi pembelian dan keterlibatan produk ramah lingkungan.

Tabel 2 Hasil Korelasi

\begin{tabular}{|c|c|c|c|}
\hline & & FREQ ordinal & GPI3 \\
\hline \multirow[t]{4}{*}{ FREQ ordinal } & Pearson & 1 & $.477^{* 8}$ \\
\hline & Correlation & & \\
\hline & $\begin{array}{l}\text { Sig. (1- } \\
\text { tailed) }\end{array}$ & & .000 \\
\hline & $\mathrm{N}$ & 126 & 126 \\
\hline \multirow[t]{4}{*}{ GPI3 } & Pearson & $.477^{* *}$ & 11 \\
\hline & Correlation & & \\
\hline & $\begin{array}{l}\text { Sig. (1- } \\
\text { tailed) }\end{array}$ & .000 & \\
\hline & $\mathrm{N}$ & 126 & 126 \\
\hline
\end{tabular}

**. Correlation is significant at the 0.01 level (1-tailed).

Seperti yang ditunjukkan pada Tabel 2, nilai korelasi antara kedua variabel adalah 0,477, yang ditemukan korelasi positif sedang. Oleh karena itu dapat diartikan bahwa frekuensi pembelian berkorelasi dengan pernyataan tentang pengulangan penggunaan green product.

Uji Korelasi 2: Frekuensi Pembelian dan attitude environment 
Tabel berikut menunjukkan hasil dan attitude environment korelasi antara Frekuensi Pembelian

Tabel 3 Hasil Korelasi

\begin{tabular}{|c|c|c|c|}
\hline & & FREQ_ordinal & EA \\
\hline \multirow[t]{4}{*}{ FREQ_ordinal } & Pearson & 1 & $.512^{* *}$ \\
\hline & Correlation & & \\
\hline & $\begin{array}{l}\text { Sig. (1- } \\
\text { tailed) }\end{array}$ & & .000 \\
\hline & $\mathrm{N}$ & 126 & 126 \\
\hline \multirow[t]{4}{*}{ EA } & Pearson & $.512^{* *}$ & 1 \\
\hline & Correlation & & \\
\hline & $\begin{array}{l}\text { Sig. (1- } \\
\text { tailed) }\end{array}$ & .000 & \\
\hline & $\mathrm{N}$ & 126 & 126 \\
\hline
\end{tabular}

**. Correlation is significant at the 0.01 level (1-tailed).

Seperti yang ditunjukkan pada Tabel 3, nilai korelasi antara kedua variabel adalah 0,512, yang ditemukan korelasi positif sedang, oleh karena itu dapat diartikan bahwa frekuensi pembelian berhubungan dengan sikap lingkungan.
Korelasi ini menunjukkan semakin sering pembeli mendapat skor tinggi dalam sikap lingkungan mereka. Kesimpulannya, konsumen yang lebih peduli terhadap lingkungan cenderung membeli lebih banyak produk ramah lingkungan. 
Tabel 4 Hasil Korelasi

PCI

FREQ_ordinal

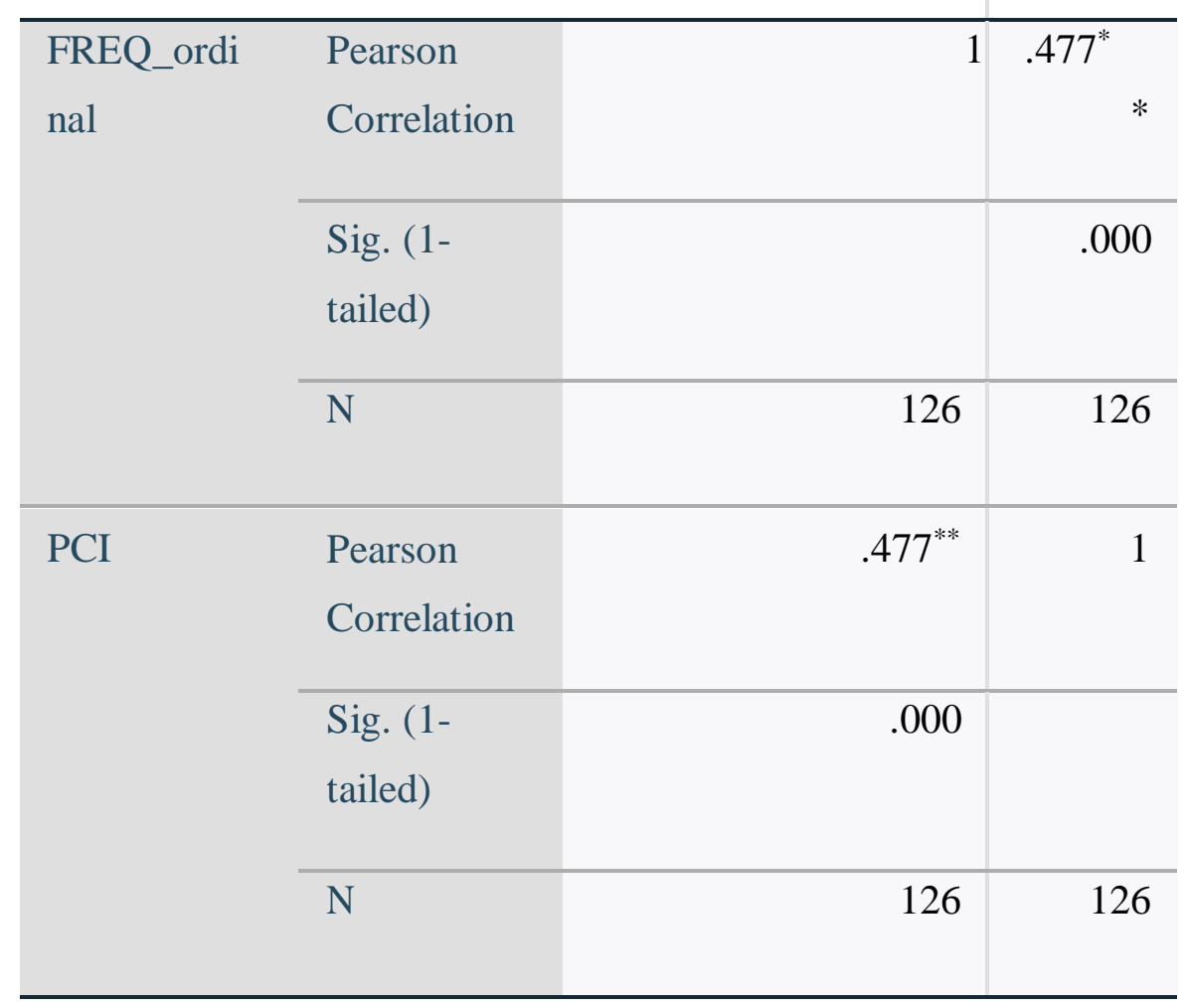

**. Correlation is significant at the 0.01 level (1-tailed).

Seperti yang ditunjukkan pada Tabel 4, nilai korelasi antara kedua variabel adalah 0,477, yang ditemukan memiliki hubungan positif sedang. Oleh karena itu dapat diartikan bahwa frekuensi pembelian berhubungan dengan keterlibatan pembelian. Korelasi ini menunjukkan bahwa pembeli yang lebih sering mendapat skor tinggi dalam keterlibatan pembelian mereka. Kesimpulannya, konsumen yang menghabiskan lebih banyak pemikiran dan proses sebelum membeli produk ramah lingkungan lebih cenderung menjadi orang yang melakukan pembelian berulang. Namun, ini bukan argumen mutlak, karena ada sejumlah pembelian yang mana dilakukan secara tidak sengaja, dan biasanya, di mana proses pembelian membutuhkan proses yang lebih sedikit, sehingga keterlibatan pembelian lebih sedikit.

Uji korelasi 3: Frekuensi pembelian dan keterlibatan produk ramah lingkungan 
Tabel berikut menunjukkan hasil asosiasi frekuensi pembelian dan korelasi antara (FREQ) dan (GPI). Oleh keterlibatan produk hijau.

karena itu, korelasi berikut menguji

Tabel 5 Hasil Korelasi

\begin{tabular}{|c|c|c|c|}
\hline \multirow[t]{3}{*}{$\begin{array}{l}\text { FREQ_ordi } \\
\text { nal }\end{array}$} & $\begin{array}{l}\text { Pearson } \\
\text { Correlation }\end{array}$ & 1 & $\begin{array}{r}.556^{*} \\
*\end{array}$ \\
\hline & $\begin{array}{l}\text { Sig. (1- } \\
\text { tailed) }\end{array}$ & & .000 \\
\hline & $\mathrm{N}$ & 126 & 126 \\
\hline \multirow[t]{3}{*}{ GPI } & $\begin{array}{l}\text { Pearson } \\
\text { Correlation }\end{array}$ & $.556^{* *}$ & 1 \\
\hline & $\begin{array}{l}\text { Sig. (1- } \\
\text { tailed) }\end{array}$ & .000 & \\
\hline & $\mathrm{N}$ & 126 & 126 \\
\hline
\end{tabular}

**. Correlation is significant at the 0.01 level (1-tailed).

Seperti yang ditunjukkan pada Tabel 5 , nilai korelasi antara kedua variabel adalah 0,556, yang ditemukan memiliki hubungan positif sedang. Oleh karena itu dapat diartikan frekuensi pembelian tersebut berkorelasi dengan keterlibatan pembelian. Hubungan ini paling kuat dibandingkan dengan korelasi sebelumnya. Korelasi ini menunjukkan bahwa pembeli yang lebih sering mendapat skor tinggi dalam keterlibatan produk mereka. Kesimpulannya, konsumen yang lebih suka menggunakan produk ramah lingkungan lebih cenderung melakukan pembelian berulang, yang juga terdengar logis. Motivasi pembelian menunjukkan bahwa preferensi produk adalah salah satu motivasi teratas. Oleh karena itu, menyarankan kualitas produk, dan pemasaran hijau dapat dikaitkan dengan jumlah pembelian. 
Analisis regresi

Analisis regresi merupakan salah satu metode statistik untuk mengukur hubungan, terutama pengaruh variabel independen terhadap variabel dependen. Oleh karena itu berkenaan dengan hipotesis yang dirumuskan, dilakukan uji regresi berganda untuk $\mathrm{H}_{1}$ dan $\mathrm{H}_{3}$, dilanjutkan dengan uji regresi sederhana untuk $\mathrm{H}_{2}$. $\mathrm{R}$ square mengukur persentase seberapa dekat data variabel agar sesuai dengan model regresi. Tingkat minimum $\mathrm{R}$ square yang dapat diterima adalah 25\%. Selain itu, nilai Beta mengukur kekuatan pengaruh antara variabel independen dan dependen. Oleh karena itu, pada uji regresi berganda, nilai beta akan menentukan variabel independen mana yang memiliki pengaruh lebih besar terhadap hubungan tersebut. Terakhir, untuk menyimpulkan pengaruh setiap pasangan variabel, nilai signifikansi harus diperhitungkan. Dengan tingkat kepercayaan $95 \%$ pengaruh positif akan muncul jika nilai signifikansi dibawah 0,05. Di sisi lain, nilai signifikansi di atas 0,05 akan memberikan pengaruh negatif, sehingga membuat nilai beta menjadi negatif juga. Nilai signifikansi akan menentukan kesimpulan atas hipotesis.

Uji regresi berganda: $\mathrm{H}_{1}$ dan $\mathrm{H}_{3}$

Pengujian pertama yang dilakukan adalah uji regresi berganda untuk attitude environment dan keterlibatan green product sebagai variabel bebas, dan keterlibatan pembelian green product sebagai variabel terikat. Hubungan ini dihipotesiskan untuk hipotesis 1 dan 3. Tabel berikut menunjukkan hasil pengujian beserta nilai kepentingan.

Tabel 6 Hasil Regresi Berganda

\begin{tabular}{|c|c|c|c|c|c|c|}
\hline $\begin{array}{l}\text { Dependent } \\
\text { variable }\end{array}$ & $\begin{array}{l}\text { Independent } \\
\text { variable }\end{array}$ & $R$ square & Beta & ANOVA & Sig. & Conclusion \\
\hline \multicolumn{7}{|c|}{$\begin{array}{l}\text { Green product } \\
\text { purchase } \\
\text { involvement }\end{array}$} \\
\hline & $\begin{array}{l}\text { Environmental } \\
\text { Attitude }\end{array}$ & .644 & .311 & 0.000 & .000 & $\begin{array}{l}\text { Positively } \\
\text { influence }\end{array}$ \\
\hline & $\begin{array}{l}\text { Green Product } \\
\text { involvement }\end{array}$ & & .579 & & .000 & $\begin{array}{l}\text { Positively } \\
\text { influence }\end{array}$ \\
\hline
\end{tabular}


Seperti yang ditunjukkan pada Tabel 6 , nilai $\mathrm{R}$ square sebesar 0,644 ditemukan sangat tinggi di atas $25 \%$, artinya data pada variabel tersebut layak untuk analisis regresi. Selanjutnya nilai beta menunjukkan bahwa kedua variabel independen memiliki nilai positif yang berarti berpengaruh positif terhadap variabel dependen. Hal ini juga didukung oleh tingkat signifikansi yang lebih kecil dari 0,05 yang berarti bahwa sikap lingkungan, dan keterlibatan green product memang berpengaruh positif terhadap keterlibatan pembelian green product. Hasil dari uji regresi berganda ini mendukung hipotesis 1 dan 3 untuk diterima. Selain itu, nilai beta menunjukkan bahwa keterlibatan produk ramah lingkungan lebih mempengaruhi keterlibatan pembelian produk ramah lingkungan daripada attitude environment. Dengan demikian, ini dapat diartikan bahwa lebih banyak penggunaan produk ramah lingkungan akan lebih mungkin untuk merangsang lebih banyak keterlibatan pembelian, atau pembelian itu sendiri.

Uji regresi sederhana: $\mathrm{H}_{2}$

Pengujian kedua yang dilakukan adalah uji regresi linier sederhana terhadap attitude environmet sebagai variabel bebas, dan keterlibatan green product sebagai variabel terikat. Hubungan ini dihipotesiskan untuk hipotesis 2. Tabel berikut menunjukkan hasil pengujian beserta nilai kepentingan

Tabel 7 Hasil Regresi Sederhana

\begin{tabular}{|l|l|l|l|l|l|l}
\hline $\begin{array}{l}\text { Dependent } \\
\text { variable }\end{array}$ & $\begin{array}{l}\text { Independent } \\
\text { variable }\end{array}$ & R square & Beta & ANOVA & Sig. & Conclusion \\
\hline $\begin{array}{l}\text { Green product } \\
\text { involvement }\end{array}$ & $\begin{array}{l}\text { Environmental } \\
\text { Attitude }\end{array}$ & .347 & .589 & 0.000 & .000 & $\begin{array}{l}\text { Positively } \\
\text { influence }\end{array}$ \\
\hline
\end{tabular}


Seperti yang ditunjukkan pada tabel di atas, nilai $R$ square sebesar 0,347 ditemukan hanya sedikit di atas tingkat penerimaan $25 \%$, artinya data pada variabel-variabel tersebut cukup sesuai untuk analisis regresi. Selanjutnya nilai beta menunjukkan bahwa variabel independen memiliki nilai positif yang berarti berpengaruh positif terhadap variabel dependen. Hal ini juga didukung oleh tingkat signifikansi yang lebih kecil dari 0,05 yang berarti bahwa attitude environment berpengaruh positif terhadap keterlibatan green product. Hasil dari uji regresi berganda ini mendukung hipotesis 2 untuk diterima. Selain itu, nilai beta lebih tinggi dari pengujian sebelumnya. Hal

\section{SIMPULAN}

Berdasarkan pembahasan yang telah dikemukakan sebelumnya, maka dapat disimpulkan dari penelitian ini antara lain:

Pengujian pertama yang dilakukan adalah uji regresi berganda untuk attitude environment dan keterlibatan green product sebagai variabel bebas, dan keterlibatan pembelian green product sebagai variabel terikat menunjukkan bahwa kedua variabel independen memiliki nilai positif yang ini menunjukkan bahwa hubungan variabel tertentu ini memiliki pengaruh yang paling kuat dibandingkan dengan hubungan yang dihipotesiskan lainnya. Hubungan tersebut menunjukkan bahwa tingkat attitude environment konsumen memengaruhi keterlibatan green product. Artinya, kepedulian konsumen terhadap lingkungan kemungkinan besar akan menentukan tingkat penggunaannya. Argumen ini dapat dikaitkan dengan uji korelasi dimana semua variabel ditemukan berhubungan dengan frekuensi pembelian produk ramah lingkungan, serta pada uji regresi berganda sebelumnya di mana attitude environment memengaruhi keterlibatan pembelian.

berarti berpengaruh positif terhadap variabel dependen. Pengujian kedua yang dilakukan adalah uji regresi linier sederhana terhadap attitude environmet sebagai variabel bebas, dan keterlibatan green product sebagai variabel terikat menunjukkan bahwa variabel independen memiliki nilai positif yang berarti berpengaruh positif terhadap variabel dependen. Adapun saran yang diberikan dalam penelitian ini adalah hendaknya setiap industri produk agar dapat memberikan persepsi yang baik 
dengan cara membuat kemasan produk dengan menggunakan bahan yang dapat didaur ulang atau dengan cara tidak menggunakan hewan untuk uji coba pada produk yang akan dijual serta memberikan promosi menarik dengan cara membuat promosi diskon setiap bulannya kepada konsumen dalam meningkatkan minat beli terhadap produk tersebut akan tetapi tidak terlepas pada konsep green marketing

\section{DAFTAR PUSTAKA}

Arafah, W. (2018). Marketing of Green Product in Indonesia Context Today. British Journal of Marketing Studies, 52-57.

Ariely, D. (2010). Predictably

Irrational. New York: Harper Perennial.

Budiman, A. (2013, April).

Understanding the Diversity of Indonesia's Consumers. Retrieved Januari 2021, from https://www.mckinsey.com/feat uredinsights/asiapacific/understandin g-the-diversity-of-indonesiasconsumers dan bagi para peneliti yang ingin melanjutkan penelitian ini atau melakukan penelitian dengan topik ini, penulis mengharapkan agar dapat menambahkan variabel-variabel lain yang dapat mempengaruhi perilaku konsumen yang mana tidak telepas dengan konsep keberlanjutan lingkungan.

Durham, G., \& Santhanakrishnan, M. (2016). Ticker fluency, sentiment, and asset valuation. The Quarterly Review of Economics and Finance, 61, 89-96.

Esmaeilpour, M., \& Bahmiary, E. (2017). Investigating the impact of environmental attitude on the decision to purchase a green product with the mediating role of environmental ., (pp. 297$315)$. 
Graham, B., \& Zweig, J. (2006). The

Intelligent Investor: The

Definitive Book on Value Investing. A Book of Practical Counsel (Revised Edition). New York: Collins Business.

Green, T. C., \& Jame, R. (2013).

Company name fluency, investor recognition, and firm value. Journal of Financial Economics , 109 (3), 813-834.

Kahneman, D. (2013). Think Fast and Slow. New York: Farrar, Straus and Giroux. Lu, L., Bock, D., \& Joseph, M. (2013). Green marketing: What the Millennials buy. Journal of Business Strategy .

Markowitz, H. (1952). Portfolio

Selection. The Journal of Finance, 7, 77-91.

Nielsen. (2018, November). The

Evolution of The Sustainability Mindset. Retrieved Januari 12, 2021

Pickett, B. J., \& Ozaki, R. (2008). Pro environmental products: marketing influence on consumer purchase decision.
Journal of Consumer Marketing , 281-293.

Rastogi, A., \& Pant, L. (2018). A Study on Green Marketing: its Use and Importance.

Ross, S. A., Westerfield, R. W., Jordan, B. D., Lim, J., \& Tan, R. (2014). Fundamental of Corporate Finance Asia Global Edition. McGraw Hill.

Schiffman, L. G., \& Wisenbilt, J. (2019). Consumer behavior. Harlow: Pearson.

Septifani, R., Achmadi, F., \& Santoso, I. (2014). Pengaruh Green Marketing, Pengetahuan dan Minat Membeli terhadap Keputusan Pembelian. Jurnal Manajemen Teknologi , 201218.

Thaler, R. (2016). Misbehaving: The Making of Behavioral Economics. New York: W. W. Norton \& Company.

Thaler, R. (2009). Nudge: Improving Decisions About Health, Wealth, and Happiness. New York: Penguin. 
Xing, X., Anderson, R., \& Hu, Y. (2016). What's a name worth? The impact of a likeable stock ticker symbol on firm value. Journal of Financial Markets , 31, 63-80.
YiLin, W. (2010). What's in a name? What leads a firm to change its name and what the new name foreshadwos. Journal of Banking \& Finance , 34, 13441359. 